\title{
YHTEISÖLLINEN TYÖHYVINVOINTI
}

\section{YTY-hankkeen havaintoja psykiatrisesta asumiskuntoutuksesta}

Yhteisöllinen työhyvinvointi (YTY) -tutkimusja kehittämishankkeessa (2015-2016) on tarkasteltu yhteisöllistä työhyvinvointia psykiatrisissa asumispalveluissa. Toimintatutkimus on toteutettu työnohjauksen näkökulmasta, mutta tavoitteena on malli, jossa yhteisöllinen työhyvinvointi rakentuu organisaatioiden kommunikaatiosuhteissa laajemmin. Aineistoina ovat olleet Webropol-kysely henkilöstölle ( $\mathrm{N}=300$, vastausprosentti 56), työnohjausistuntojen seurantapäiväkirjat $(\mathrm{N}=232)$, lukuisat esimiesten ja johdon haastattelut ja kehittämiskokousten keskustelut, kuusi työnohjaajien haastattelua sekä kahdeksan henkilöstön työpajaa.

Lähtökohtana tutkimukselle on ollut oletus, että yhteisöllisyys työssä ja arjessa luo hyvinvointia ja että yhteisöön kuuluminen on yksi ihmisen perustarpeista, joten sitä kannattaa tukea myös työssä. Tutkimusten mukaan (ks. esim. Hyyppä 2002, Lindfors 2007, Sinokki 2010, Manka 2013) yhteisöllisyys lisää fyysistä ja psyykkistä terveyttä, esimerkiksi siksi, että sen kautta saatava sosiaalinen tuki lisää voimavaroja, jotka auttavat muun muassa stressin hallinnassa.

Yhteisöllisyydellä katsotaan olevan paljon myönteisiä seurauksia. Hyväksi koetusta yhteisöllisyydestä seuraa työelämäkontekstissa sitoutumista, työtyytyväisyyttä, työhyvinvointia sekä työn hyvää laatua. (Lampinen ym. 2013.) Yhteisöllisyydellä tuetaan organisaation kokonaisuuden toimivuutta ja oppimiskykyä sekä työn hallintaa, sillä yhteisölli- syys lisää sosiaalista ja psykologista pääomaa (Manka 2013). Yhteisöllä ajatellaan olevan niin sanottu kollektiivinen identiteetti, joka on yhteisöä koossa pitävä "liima”. Parhaimmillaan yhteisö myös tukee yksilöidentiteetin eheyttä ja samalla kasvattaa ryhmän jäsenten välistä luottamusta, yhteishenkeä ja osallistumista, jotka ovat sosiaalisen pääoman osatekijöitä (esim. Coleman 1988, 101).

Tässä kirjoituksessa pohdimme yhteisöllisyyttä työympäristöissä, joissa työntekijöiden perustyöhön kuuluu olennaisesti ihmisten välinen vuorovaikutus. Psykiatrisissa asumispalveluissa tarjotaan psyykkisesti pitkäaikaissairaille turvallinen, kodikas ja toimintakykyä ylläpitävä asumismuoto sekä yhteisöön liittymisen mahdollisuus. Henkilökunta on paikalla ympäri vuorokauden. Erityisesti tällaisessa työympäristössä tarvitaan keinoja henkilöstön psyykkisen kuormituksen vähentämiseksi. YTY-tutkimuksessa, jonka lopputulokset raportoidaan lokakuussa, keskitymme työyhteisöllisyyteen organisaation kommunikaatiosuhteiden näkökulmasta sekä työnohjauksen vaikutuksiin yhteisöllisyyden rakentamisessa. Tässä katsauksessa kuvaamme yhteisöllisyyden luonteeseen liittyviä havaintojamme. Kirjoituksen aineistolainaukset ovat peräisin tutkimusaineiston niistä osista, joissa yhteisöllisyyttä on erityisesti pohdittu: esimiesten ja johdon haastatteluista ja kehittämiskokousten keskusteluista sekä henkilöstön työpajaaineistosta. Lainaukset on valittu kuvaamaan analyysissä todettua, kokonaisuudessa yhtei- 
seksi koettua ilmiötä laadullisen tutkimuksen periaatteita noudattaen.

\section{Myönteinen ja kielteinen yhteisöllisyys}

Yhteisöön ja yhteisöllisyyteen liittyy myönteisiä mielikuvia. Ihmiset kaipaavat yhdessä olemista ja tekemistä, kokemusta merkityksellisistä suhteista ja yhteenkuuluvuudesta. Sosiologisena tutkimuskohteena yhteisöllisyys on kiinnostanut lähtien Tönniesin (2001, alkuperäinen 1887) Gemeinschaft ja Gesellschaft -jaottelusta, joka on luonut perustaa yhteiskunnan sekä ihmisten lähiyhteisöjen, kuten työyhteisöjen ja perheen, analyysille. Sosiologiassa yhteisöllisyyttä on tarkasteltu yhteiskuntia, ryhmiä ja kulttuureja koossapitävänä voimana. Yhteisöllisyys on kiinnostanut myös muita ihmistä tutkivia tieteenaloja, kuten psykologiaa ja sosiaalipsykologiaa.

Psykiatrisissa asumispalveluissa arvona on myönteinen yhteisöllisyys, jota pyritään toteuttamaan organisaatiota läpileikkaavasti yhteisöllisten rakenteiden tukemissa käytännöissä. Yhteisöllisyys muodostuu kuitenkin elävässä elämässä ihmisten välisessä vuorovaikutuksessa, ja tästä seuraa se, ettei yhteisöllisyys asetu helposti organisaation strategian tarkoittamaksi toiminnaksi. "Normittaminen nappaa aina vallan hyviltä tavoitteilta." Hyvän yhteisöllisyyden kriteerit voidaan strategisesti asettaa, mutta yhteisöllisyyden toteutumista tulkitaan inhimillisinä kokemuksina. Paasivaaran ja Nikkilän (2010) mukaan yhteisöllisyys ei ole itsestään selvästi ihannetila. Sillä on myös kielteiset puolensa. Jos hyvänä koettu yhteisö on siihen kuuluville hyvän elämän perusta, kielteinen yhteisöllisyys puolestaan tukahduttaa.

Toisaalta normien ja selkeyden puute hajottaa työyhteisöllisyyttä. Yhteisten tavoitteiden sijasta toiminta perustuu välinpitämättömyyteen, jolloin ihmiset rutiininomaisesti suorittavat tehtäviään ilman henkilökohtaisesti motivoivia tavoitteita ja merkityksiä, tai yksittäisten työntekijöiden omiin intresseihin ja työtapaan. Yhteisöllisyyden puute puolestaan voi ilmetä vuorovaikutuksen puutteena, puhumattomuutena, tekemättä jättämisenä, yhteisen tavoitteen puuttumisena (ks. Paasivaara \&t Nikkilä 2010).

Pohjimmiltaan yhteisön ja yhteisöllisyyden ydin on ryhmässä ja sen jäsenten välisessä vuorovaikutuksessa. Ryhmää yhdistää yhteinen tehtävä ja päämäärä. (Ks. esim. Lehtonen 1990, Paasivaara \&t Nikkilä 2010.) Yksilölliset kokemusmaailmat, käsitykset ja tunteet kohtaavat yhteisöä rakentavassa tai purkavassa vuorovaikutuksessa. Sosiaalisella yhteisöllä ei kuitenkaan ole muistia, ja siksi yksilöiden "sense of community" on kantava voima yhteisöllisyyden rakentamisessa (ks. esim. Leydesdorff 2003, 7). Vaikka työorganisaatio määrittää tietyt pelisäännöt ja normit, myös yksilöt vaikuttavat yhteisön toimivuuteen valinnoillaan kaikissa organisaation tehtävärooleissa.

Organisaation menestystä aikaansaava, yhteisiä merkityksiä luova yhteisöllinen kommunikaatio särkyy, jos yksilönä pärjääminen korostuu yhteisöllisyyden kustannuksella. Henkilökohtaiset tulostavoitteet ja kilpailullisuus pelottavat ihmistä yhteisöllisyyden ääreltä (ks. esim. Paasivaara \&t Nikkilä 2010, Henttonen \&t Lapointe 2015). Yhteistä keskustelua yhteisen perustehtävän tekemisestä ei tällöin avata, vaan kilpaillaan siitä, kuka yksilö tekee työn parhaiten. On myös mahdollista, että organisaation sisäinen kilpailullisuus eristää eri näkökantoja edustavat tai eri tehtäviä suorittavat työntekijät toisistaan ja luo toisilleen vastakkaisia tiiviitä ryhmittymiä. Kilpaillaan oikeassa olemisesta ja vallasta. "Ei kilpailtaisi vallasta, vaan innostuttaisiin kilvoittelemaan hyvän työn tekemisestä, ja organisaation onnistuminen olisi kaikkien yhteisenä tavoitteena."

Kilpailullisuuden vastapainona niin julkisuudessa kuin tutkimissamme organisaatioissa ylläpidetään keskusteluja me-hengen, sosiaalisen ja psykologisen pääoman, työhön sitoutumisen, luovuuden ja luottamuksen sekä yhteisöllisen työhyvinvoinnin merkityksellisyydestä. Sosiaalisen ja psykologisen pääoman lisääntyessä myös hyvä yhteisöllisyys lisääntyy (Lampinen ym. 2013). Sosiaalinen pääoma on tärkeä yhteisöllisyyden psyykkis- 
tä ja taloudellista hyvinvointia avaava käsite mutta tässä yhteydessä liian mahtipontinen ja laaja (ks. esim. Kajanoja 2009). Työyhteisössä toiminta on työyhteisön jäsenten välistä näkemysten, kokemusten ja tietojen käsittelyä, mikä puolestaan onnistuakseen edellyttää jäsenten välistä luottamusta ja sitoutumista yhteisön tehtävään (Paasivaara \&t Nikkilä 2010, 46). Psykiatrisissa asumispalveluissa yhteisöllisyys on läsnä päivittäisessä työssä työntekijöiden välillä ja asukkaiden kanssa. Kaikkina hetkinä yhteisöllisyys ei näyttäydy kaikille myönteisenä. Yhteisenä arvona myönteinen yhteisöllisyys kuitenkin selkeästi ohjaa kaikkea vuorovaikutusta.

\section{Millaista yhteisöllisyyttä viritetään psykiatrisissa asumispalveluissa?}

Psykiatrisissa asumiskuntoutuspalveluissa liikutaan päivittäin eri tilanteissa erilaisten yhteisöllisyyksien rajapinnoilla. Psykiatrinen asumiskuntoutusympäristö on työntekijöiden työpaikka ja samalla asukkaiden koti. Työyhteisön jäseniä yhdistää yhteinen perustehtävä. Psykiatrisessa työssä asiakkaiden sairaudet tuovat työntekijöiden ja asiakkaiden väliseen vuorovaikutukseen piirteitä, joissa työntekijän ammatillisuus tarjoaa keinoja ja oman identiteetin suojaa. Erityisiä työssä jaksamisen haasteita syntyy kuitenkin siitä, että ihmisen mielen hauraus tulee lähelle inhimillisenä kokemuksena. Lisäksi työtä tehdään asukkaan yksityisessä tilassa, kodissa.

Ammattilaisten tehtävänä on luoda turvallista ja ennustettavissa olevaa struktuuria, joka mahdollistaa asukkaalle sairaudesta huolimatta kodinomaisen ja mahdollisimman itsenäisen asumisen. Kodinomaisuuden luomisen ja esimerkiksi hoidollisen ammatillisuuden ylläpitämisen tehtävät tekevät työyhteisön roolien määrittelyn ja toteuttamisen käytännössä haasteelliseksi. Työntekijät voivat myös keskenään olla eri mieltä siitä, millaisella tavalla ammatillisuutta osoitetaan vuorovaikutuksessa asukkaan kanssa.

Työntekijät pyrkivät ratkaisemaan kodinomaisen ja työympäristöön kuuluvan ammatillisen yhteisöllisyyden kohtaamis- ta ja ristiriitoja. Tervehtiminen, kohteliaisuus, "normaaliarjen" ilmapiirin ylläpitäminen, läsnäolo, ajan antaminen tarvitsevalle sekä puhtaudesta huolehtiminen ovat tärkeitä asukkaan tukemisen keinoja. Perustehtävästä keskusteltaessa keskustellaan myös eri näkemyksistä siitä, mikä perustehtävässä on tärkeintä. Painotetaanko työssä arjen askareita, hoidollisia ja lääkinnällisiä tehtäviä vai ammatillisuuden reflektointiin perustuvaa asiakkaan ohjausta. Viimeksi mainittu tarkoittaa esimerkiksi kuntouttavan työotteen tai Recovery-työotteen (lyhyesti: asukkaan myönteistä kannustamista omaehtoiseen elämäänsä osallistumiseen) (ks. esim. Nordling 2015) tietoista käyttöön oton harjoittelua asiakastyössä tai omaohjaajuuden ytimien pohdintaa. Merkityksiä luova kommunikaatio liikkuu tällöin arjen askareita ja ammatillisia työkäytäntöjä abstraktimmeissa asioissa, kuten arvoissa. Yhteisöllisyydessä on myös läheisyyttä (ks. Lindfors 2007) jollain tavalla läsnä, mutta asukkaisiin pidetään etäisyyttä.

Tutkimus- ja kehittämistyön aikana on noussut tärkeäksi yhteisöllisyyttä edistäväksi asiaksi erilaisten ajatusten, toimintatapojen ja persoonien hyväksyminen. Työntekijät ovat olleet hämmentyneitä havaitessaan, kuinka erilaisia ajattelu- ja työn tekemisen tapoja tutuillakin kollegoilla on. Asioista keskustelemisen kautta on saatu tilaisuuksia oppia uusia käytäntöjä, saatu uutta näkökulmaa omaan työhön ja myös tilaisuuksia saada ja antaa palautetta onnistuneista ratkaisuista. Rohkeus avoimeen keskusteluun on myös lisääntynyt hankkeen aikana. Tämä puolestaan on edistänyt paitsi oppimista, myös työyhteisön yhteisen arvoperustan konkretisoitumista yhteisesti avatuksi ymmärrykseksi. Perustehtävään liittyvät keskustelut sekä työnohjauksen tarkoituksen pohtiminen ovat selkeästi lisänneet työyhteisöjen yhteisiä näkemyksiä työpaikan arvoista. Miten asukasta autetaan kiinnostumaan omasta arjestaan hänen vakavasta psyyken sairaudestaan huolimatta? Miten havaita pienikin kiinnostuksen pilkahdus? Miten työntekijän omat oletukset asukkaan kyvyistä vaikuttavat työntekijän valintoihin hänen toimiessaan asukkaan kanssa? 
Työtilanteissa työntekijät joutuvat jatkuviin roolivaihdoksiin, joita ei välttämättä arjessa analyyttisesti avata. Ne voivat aiheuttaa erilaisia ristiriitaisia tunteita sekä psyykkistä kuormitusta ja vaikuttaa myös työyhteisön ilmapiiriin. Kodin roolien ja ammatillisten roolien rajanvetojen lisäksi "persoonalla" työskentely nousi myöskin puheenaiheeksi YTY-hankkeessa ja johti keskusteluun työpaikan käyttäytymissäännöistä ja yksiköiden suhteesta toisiinsa, esimiehiin ja johtoon.

Perustehtäviin kuuluu hoidollisen työn lisäksi myös tarvittaessa auttaa asukasta saamaan kauppapalveluita, ohjata ja kannustaa osallistumaan harrastustoimintaan ja niin edelleen. Asukkaan itsenäisyyttä tukiessaan työntekijät samalla tarkkailevat asukkaan edistymistä, ja heidän tulee ajoittain myös arvioida, ovatko asiakkaat oikeassa paikassa juuri tässä asumismuodossa. Olisiko heillä kuitenkin mahdollisuus asua itsenäisemmin? Ammattilainen tarkastelee asukkaan kuntoutumisen mahdollisuuksia myös kriittisestä näkökulmasta. Kodinomaisuus kärsii, jos asumispalvelut koetaan jonkinlaisena säilytyspaikkana. Näiden ristiriitaistenkin roolien kokoajana on terveys-, hoito- ja/tai kuntoutusalan ammattilainen, joka lisäksi kykenee joustamaan rahoittajien, organisaation ja yhteiskunnan muutostrendien mukaan.

Työntekijät tukevat toisiaan työssä, jossa asukkaiden sairauksien luoma kaoottisuus tekee työympäristöstäkin usein "psykoottisen." Yksin on vaikea pärjätä ympäristössä, jossa sairaudet määrittävät käyttäytymisen normaaliutta arjessa. "Epänormaali muuttuu normaaliksi”, mikä tarkoittaa, että sopeudutaan psykiatristen sairauksien maailmaan. Ammatillinen työyhteisöllisyys tukee etäisyyden pitämisessä. Työyhteisö ja sen erilaiset ihmiset tarjoavat peilin, jonka kautta voi tutkia omaa rooliaan arjessa, työntekijänä tai asukkaana. "Yhteisöltä saa palautteen, jota vasten peilata yksilöllisiä tarpeita ja haaveita." Hyvä työyhteisö tukee myös jäsentensä psyykkistä terveyttä haastavassa työympäristössä. "Työyhteisölle käy koko ajan niin, että psykoottisuus tarttuu” ja psykoottiseen työympäristöön voi sopeutua "liikaa".
Paasivaaran ja Nikkilän (2010) mukaan myös ihmisten valmius osallistua yhteisöllisyyden rakentamiseen vaihtelee. Ihmisten asenteet ja motivaatiotilat vaikuttavat siihen, kuinka paljon halutaan olla tekemissä toisten kanssa ja kuinka paljon yhteisön tarpeisiin sitoudutaan.

Nordlingin (2015) mukaan yhteisöllisyys työssä tarkoittaa, että luodaan turvallinen, vastuullinen ja ennustettavissa oleva työn struktuuri. Asiakastyössä tämä tarkoittaa, että asiakkaita hoidetaan yhteisen suunnitelman ja yhteisten pelisääntöjen mukaan. Yhteisiä sopimuksia kunnioitetaan ja niihin sitoudutaan. Yhteisöllisyys tarkoittaa yhdessä tekemistä, yhdessä läsnä olemista yhteisesti sovituissa hetkissä ja paikoissa, yhdessä toimimista ja keskustelua tasavertaisten, mutta keskenään erilaisten, ihmisten välillä. (Ks. myös Paasivaara \&t Nikkilä 2010.) "Hyvä työyhteisö antaa selkeän viitekehyksen, toimintaympäristön.”

YTY-hankkeen tärkeänä näkökulmana ja työtapana on ollut positiivinen psykologia. Myönteisyys ja huumori on myös otettu työorganisaatioissa hankkeen ulkopuolisessa kehittämistyössä mukaan asiakastyötä suuntaavina Recovery -projekteina. Positiivinen psykologia ei kuitenkaan ole "vain" positiivisuutta ja huumoria, vaan syvällisempi pyrkimys myönteisen psykologisen pääoman kasvattamiseen työhyvinvointia luovan yhteisöllisyyden oppimisen perustana (UusitaloMalmivaara 2015, Manka ym. 2014, Luthans ym. 2007). Kuntouttava yhteisö asukkaalle voi olla myös työhyvinvointia ylläpitävä työyhteisö työntekijöille.

Kuntouttavan yhteisön edellytyksenä on (mm. Nordling 2015), että toiminnassa keskitytään perustehtävään, ylläpidetään ihmisarvoa kunnioittavaa toimintakulttuuria ja tuetaan yhteisöllisyyttä, joka puolestaan edellyttää kaikkien osallisuutta. Työn sisältöjä uskalletaan kehittää rohkeasti ja avoimesti siten, että toiminnalle, kuuntelulle ja keskustelulle etsitään synergiaa. Harjoitellaan avoimuutta, ennakkoluulottomuutta, kannustavaa ja positiiviseen palautteeseen painottuvaa ilmapiiriä. Pidetään yllä säännöllistä keskustelua ja arvi- 
ointia toiminnan edistymisestä käytännössä. "Hyvä työyhteisöllisyys mahdollistaa avoimen toiminnan, kokeilut, joissa saa myös epäonnistua."

Kaikessa yhteisöllisyyttä koskevassa on läsnä tietty epämääräisyys ja puheen abstraktius. Käsitykset esimerkiksi siitä, miten aito yhteistyö ja yhteisöllisyys toteutetaan, ovat erilaisia. Jotta yhteisöllisyyden abstraktiudesta päästään yhteiseen näkemykseen omasta yhteisöstä ja sen tavoitteista, jokaiselta tarvitaan tahtoa kuulla ja tilaa tulla kuulluksi, dialogista vuorovaikutusta ja tietoisesti yhteisiä merkityksiä etsivää kommunikaatiota. YTYhankkeen avaamat keskustelut ovat edistäneet yhteisten näkemysten syntymistä ja konkreettisia toimia esimerkiksi yhteisöllisyyttä tukevan työnohjauksen hyödyntämisessä: ”Työyhteisöllisyys edellyttää puhumista...paljon puhumista." "Yhteisten merkitysten luomista yhdessä." Yhteisöllisyyden ylläpitäminen edellyttää jatkuvan keskustelun ylläpitämistä.

\section{Yhteisöllisyyden johtaminen}

Tutkimuksessa mukana olleiden organisaatioiden käytännöllisten kehittämistehtävien yhdistäminen yhteisöllisen työhyvinvointimallin perustaksi edellyttää tarkastelun laajentamista organisaation kokonaisuuteen ja kokonaisuuden johtamiseen. Tutkimusprosessin puolivälin paikkeilla alkoi yhä vahvemmin näyttää siltä, että johtamisen merkitys yhteisöllisyyden tukijana on vahvempi kuin hankkeen alussa tunnustettiin tai tunnistettiin.

Johdon perustehtävän näkökulmasta organisaatioiden rakenteilla, strategisilla linjauksilla ja toimintatavoilla pyritään tukemaan koko organisaation perustehtävään liitettyä yhteisöllisyyden ajatusta. Tavoitteena on, että työntekijät kokisivat työskentelevänsä työpaikassa, johon voi sitoutua ja jossa voi tehdä mielekästä työtä. Organisaation sisälle kuitenkin syntyy erilaisia pienyhteisöjä yksiköittäin. Eriasteisesti autonomisten, perustehtävästään huolehtivien työyksiköiden lisäksi syntyy erilaisia muita pienyhteisöjä, joista osa on organisaatiossa sovituilla toimintatavoilla tuettavia virallisia yhteisöjä. Tällaisia ovat esi- merkiksi erilaiset asukkaiden kuntoutumista tukevat yhteisöt, kuten arjen avun verkostot. Lisäksi asukkaiden välille muodostuu myös epävirallisempia yhteisöllisyyden muotoja, ystävyys- ja muita vastaavia verkostoja. Muodostuu myös sellaisia verkostoja ja yhteisöjä, joita ei organisaation virallisella ohjauksella tueta tai haluta mahdollistaa (kuten hyväksikäytön verkostoja).

Johdon ja työntekijöiden välinen yhteys vaihtelee jonkin verran organisaatioissa. Juuri tässä vertailuasetelmassa on havaittavissa, että hyvän yhteisöllisyyden rakentamista edistää se, että johto konkreettisesti reagoi ja reflektoi myös omaa johtamistaan ja esimiestyötään havaitessaan tarvetta oman toimintansa muuttamiseen.

Johdon ja esimiesten haastatteluissa pohdittiin konkreettisia keinoja työntekijöiden kokeman hyvän työyhteisöllisyyden tukemiseen. Ensinnäkin koko organisaatiossa tulee olla yhteinen käsitys siitä, millaista työyhteisöllisyyttä tavoitellaan. Yhteisöllisyydestä on työyhteisössä erilaisia toiveita. Niistä keskustelu auttaa yhteisen tavoitteen määrittämisessä. Hyvässä työyhteisössä tuetaan yhteisten merkitysten luomisen tiloja ja mahdollistetaan vuorovaikutusta. Tästä esimerkkeinä ovat työnohjauksen tarjoaminen työntekijöille sekä työntekijöiden palautteen ja toiveiden kuuleminen työnohjauksen ja muiden työhyvinvointia edistävien toimien kehittämiseksi. Työyhteisöä kehystää perustehtävä, jossa yhteisesti sovitut arvot ja pelisäännöt (ks. esim. Räisänen \&t Lestinen 2006) luovat työntekijöille turvallisuutta, rakentavat työntekijöiden ammatillista autonomiaa tukevaa luottamusta ja lisäävät yhteisvastuullisuutta organisaation menestymisestä.

Työntekijät, esimiehet ja johto ovat eri asemassa organisaation perustehtävän, psykiatristen asumispalveluiden tuottamisen, kannalta. Johdon valittavana on erilaisia toimintatapoja suhteessa henkilöstöön: eriasteisesti kontrolloiva ja valvova tai luottamuksellista vapautta antava. Näillä valinnoilla on erilaisia seurauksia työyhteisöissä. Kaikilla työn tasoilla ja kaikissa rooleissa on kyse ihmisten välisestä kommunikaatiosta. Henkilöstön nä- 
kemyksissä yhtäältä luottamuksen osoituksena koetaan se, että työlle ja sen kehittämiselle annetaan melko autonomiset kehykset, eikä pikkuasioihin puututa. Toisaalta toivotaan, että johto olisi henkilöstölle jonkin verran konkreettisemmin läsnä, henkilöinä keskustelemassa yhteisistä asioista. Johdon ja esimiesten perustehtävänä on muun muassa muodostaa organisaatiossa sovittua yhteisöllisyyttä tukevat rakenteet ja toimintamallit sekä seurata toiminnan sujumista kokonaisuutena. Strategiset valinnat eivät aina välttämättä avaudu arjen työhön riittävällä tavalla.

\section{Olennaista on aktiivinen yhteisten merkitysten Iuominen}

Yhteisöllinen työhyvinvointimalli (YTY) -hankkeessa tutkittavat ryhmät ovat olleet kehityskaareltaan erilaisia. Ryhmien ja ryhmien jäsenten välisiä taustoja ei tätä tutkimusta varten ollut mahdollista selvittää. Yksilöiden halu auttaa toisiaan ja hyväksyä toisensa, eli työtoverin tukemisen ulottuvuus, tuli kehittämistyön aikana herätetyksi aktiivisen pohdinnan kohteeksi. Työnohjausistuntojen seurantapäiväkirjoihin ja henkilöstön työpajoihin pohjautuvat aineistot osoittavat, että työntekijät alkoivat kiinnittää enemmän hyväksyvää ja ymmärtävää huomiota oman kokemuksensa ulkopuolelle, ryhmän ja työyhteisön kokonaisuuteen. Alettiin etsiä ja löytää myönteisiä ratkaisuja yhdessä tekemisen ja oppimisen edistämiseksi turhaumissa vellomisen sijasta. Sama koskee yhteenkuuluvuuden tunnetta. Luottamus ja yhteenkuuluvuus ryhmän jäsenten kokemuksena vaikuttivat kasvavan. Samalla kun yhteenkuuluvuus ja työtoverin tukeminen lisääntyvät, myös emotionaalinen turvallisuus lisääntyy. Yhteistä arvopohjaa voidaan rakentaa avoimemmin.

Yhteisiä merkityksiä luova kommunikaatio edellyttää, että esimies ja johto myös itse luovat ja ylläpitävät keskusteluun rohkaisevaa vuorovaikutusta, jossa käsitellään organisaation perustehtävää, muutoksia, sosiaalisia suhteita, työilmapiiriä, arvoja ja yhteisiä pelisääntöjä. Tämä ei ole tehtävä, joka päättyy. Sen sijaan kyseessä on jatkumo, työpaikalla luotava toimintakulttuuri. Vuorovaikutukseen kannustaminen etäältä ei riitä yhteisöllisyyden edistämiseen. Tarvitaan esimerkiksi sitä, että työntekijöiltä kysytään, heitä kuunnellaan, heidän kanssaan keskustellaan, perustellaan, kuullaan perusteluja ja ollaan kiinnostuneita ihmisten ajatuksista, ihmetellään yhdessä ja tutkitaan ratkaisujen mahdollisuuksia monista näkökulmista.

Tutkimuksen alussa päällimmäisenä olivat muun muassa avoimuuden puute, vuorovaikutuksen ohuus ja turhautuminen joihinkin yhteisiin käytäntöihin, kuten työnohjaukseen. Kun toimintatutkimuksessa havaitaan, että interventio (asian keskusteluun nostaminen, harjoitus, tutkimuskysely tai muu) lisää työhyvinvointia luovaa yhteisöllisyyttä, on kysyttävä myös, mitä voidaan tehdä tutkimuksen päätyttyä, jotta ei palata takaisin alkuvaiheeseen. Vastaus on yksinkertainen. Tarvitaan fasilitaattori, jotta asiat pysyvät esillä riittävästi. Työpaikalla fasilitaattoreina toimivat esimies ja rakenteita luova organisaation johto. Tämä ei tarkoita, etteikö jokaisella työntekijällä erikseen ja muiden kanssa yhdessä olisi vastuu omalta osaltaan pitää kiinni yhdessä opituista asioista. Työyhteisö rakentuu vuorovaikutuksessa, jota kaikkien organisaation ja työyhteisön jäsenten tulee opetella ja tukea.

Hyvä työyhteisöllisyyden kokemus lisää uskallusta uudistua ja kohdata muutostakin uteliaasti. Se myös vahvistaa keskinäistä reiluutta, antaa tukea haastavienkin asioiden kohtaamiseen ja normalisoi tunnetäyteistä vuorovaikutusta vapautuneeksi ammatilliseksi työdialogiksi. Hyvä työyhteisöllisyys lisää yhdessä tekemisen halua, joka psykiatrisissa asumispalveluissa YTY-hankkeen havaintojen perusteella on jo vahvaa.

\section{Sirpa Mertala, YTT, erikoistutkija, Kuntoutussäätiö}

\section{Kimmo Terävä, VTM, tutkija, Kuntoutussäätiö}

\section{Lähteet}

Coleman J (1988) Social Capital in the Creation of Human Capital. American Journal of Sociology 
94, s1, 95-120. Verkkodokumentti: http://courseweb.lis.illinois.edu/ katewill/for-china/readings/ coleman\%201988\%20social\%20capital.pdf. Luettu 15.3.2016.

Henttonen E, Lapointe K (2015) Työelämän toisinajattelijat. Gaudeamus. Helsinki

Hyyppä M (2002) Elinvoimaa yhteisöistä. Sosiaalinen pääoma ja terveys. PS-kustannus. Keuruu.

Kajanoja J (2009) Sosiaalinen pääoma: yhteisöllisyyden paluuta vai henkistä väkivaltaa? Yhteiskuntapolitiikka 74, 1, 72-79.

Lampinen M-S, Viitanen E, Konu A (2013) Systemaattinen kirjallisuuskatsaus yhteisöllisyydestä työelämässä. Sosiaalilääketieteellinen aikakauslehti 50, 71-86.

Leydesdorff L (2003) Sociological theory of communication. The self-organisation of the knowledge-based society. Universal Publishers/uPUBLISH. COM.

Lindfors P (2007) Tutkimuksia, kokemuksia ja ajatuksia yhteisöllisyyden terveysvaikutuksista. Psykoterapia 25, 1, 21-37.

Luthans F, Youssef C.M, Avolio BJ (2007) Psychological capital. Oxford University Press, New York.
Manka M-L (2013) Työpaikan yhteisöllisyyden merkitys työssä jatkamisessa. Tampereen yliopisto. Johtamiskorkeakoulu. Luentomateriaali.

Manka M-L, Larjovuori R-L, Heikkilä-Tammi K (2014) Voimavarat käyttöön - miten kehittää psykologista pääomaa? Tampereen yliopiston Johtamiskorkeakoulun Tutkimus- ja koulutuskeskus Synergos, Kuntoutussäätiö, Sosiaali- ja terveysministeriö, Euroopan sosiaalirahasto.

Nordling E (2015) Näkemyksiä toipumisorientaatiosta. Terveyden ja hyvinvoinnin laitos. Luentomateriaali 3.3.2015.

Paasivaara L, Nikkilä J (2010) Yhteisöllisyydestä työhyvinvointia. Kirjapaja. Helsinki.

Räisänen K, Lestinen J (2006) Kyllin hyvä. Työterveyslaitos. Helsinki.

Sinokki M (2010) Työyhteisö - uhka ja tuki mielenterveydelle. Lääketieteellinen aikakauskirja. Duodecim 126, 15, 1803-9.

Tönnies F (2001) (alkuperäinen 1887) Community and civil society. Cambridge University Press. Cambridge.

Uusitalo-Malmivaara L (2015) Positiivisen psykologian voima. PS-kustannus. Jyväskylä.

\section{Kuntoutussäätiö}

